\title{
TMAP Wadden Sea Sedimentation Database
}

\author{
Martin Stock
}

\begin{abstract}
Elevation changes in the salt marshes of the Schleswig-Holstein Wadden Sea National Park are measured annually since 1992 in relation to sea level rise, vegetation changes and salt marsh management by means of sedimentation-erosion-bar (SEB) measurements. In total, 144 permanent plots were established along transects with a concentration to three different locations along the coast, namely the Hamburger Hallig, the salt marshes of Westerhever and on the island of Trischen. The measurements are part of the Trilateral Monitoring and Assesment Programm (TMAP) within the trilateral Wadden Sea Cooperation. The data provide a baseline for further studies of vegetation changes in salt marshes and in relation to management and coastal protection activities. This report describes the available content in the TMAP Wadden Sea Sedimentation Database (GIVD ID EU-DE-032).
\end{abstract}

Keywords: accretion; conservation; elevation change; land use; management; national park salt marsh.

GIVD Database ID: EU-DE-032

Last update: 2012-05-09

\section{TMAP Wadden Sea Sedimentation Database}

Scope: Database of measurements of elevation changes along transects in the salt marshes of Schleswig-Holstein in relation to sea level rise and vegetation changes by means of sedimentation-erosion-bar (SEB) measurements. In toal 144 permanent plots have been monitored annually since 1992.

Status: completed and continuing

Period: 1992-2011

Database manager(s): Martin Stock (martin.stock@lkn.landsh.de)

Owner: LKN-SH

Dr. Martin Stock

Nationalparkverwaltung

Schlossgarten 1

D-25832 Tönning

Web address: [NA]

Availability: according to a specific agreement

Database format(s): Excel

Publication: [NA]

Plot type(s): time series

Non-overlapping plots: 144

Total plot observations: 144

Online upload: no

Online search: no

Countries: DE: $10.0 \%$

Export format(s): Excel, CSV file, plain text file

Forest: $0 \%$ - Non-forest: aquatic: $0 \%$; semi-aquatic: $0 \%$; arctic-alpine: $0 \%$; natural: $0 \%$; semi-natural: $0 \%$; anthropogenic: $0 \%$

Guilds: all vascular plants: $100 \%$

Environmental data: altitude: $100 \%$; other soil attributes: $100 \%$

Performance measure(s): [NA]

Geographic localisation: GPS coordinates (precision $25 \mathrm{~m}$ or less): $100 \%$

Sampling periods: [NA]

Information as of 2012-07-12; further details and future updates available from http://www.givd.info/ID/EU-DE-032

Martin Stock (martin.stock@1kn.landsh.de)

Umweltbeobachtung und Planungsgrundlagen, Nationalparkverwaltung, Schlossgarten 1, 25832 Tönning, GERMANY 